UCRL-JC-120957

PREPRINT

\title{
Analysis of Near-Field Thermal and Psychometric Waste Package Environment Using Ventilation
}

\author{
G. Danko \\ T. A. Buscheck \\ J. J. Nitao \\ S. Saterlie \\ This paper was prepared for submittal to the \\ American Nuclear Society's \\ International High Level Radioactive Waste Management Conference \\ Las Vegas, NV \\ May 1 - 5, 1995
}

March 1995

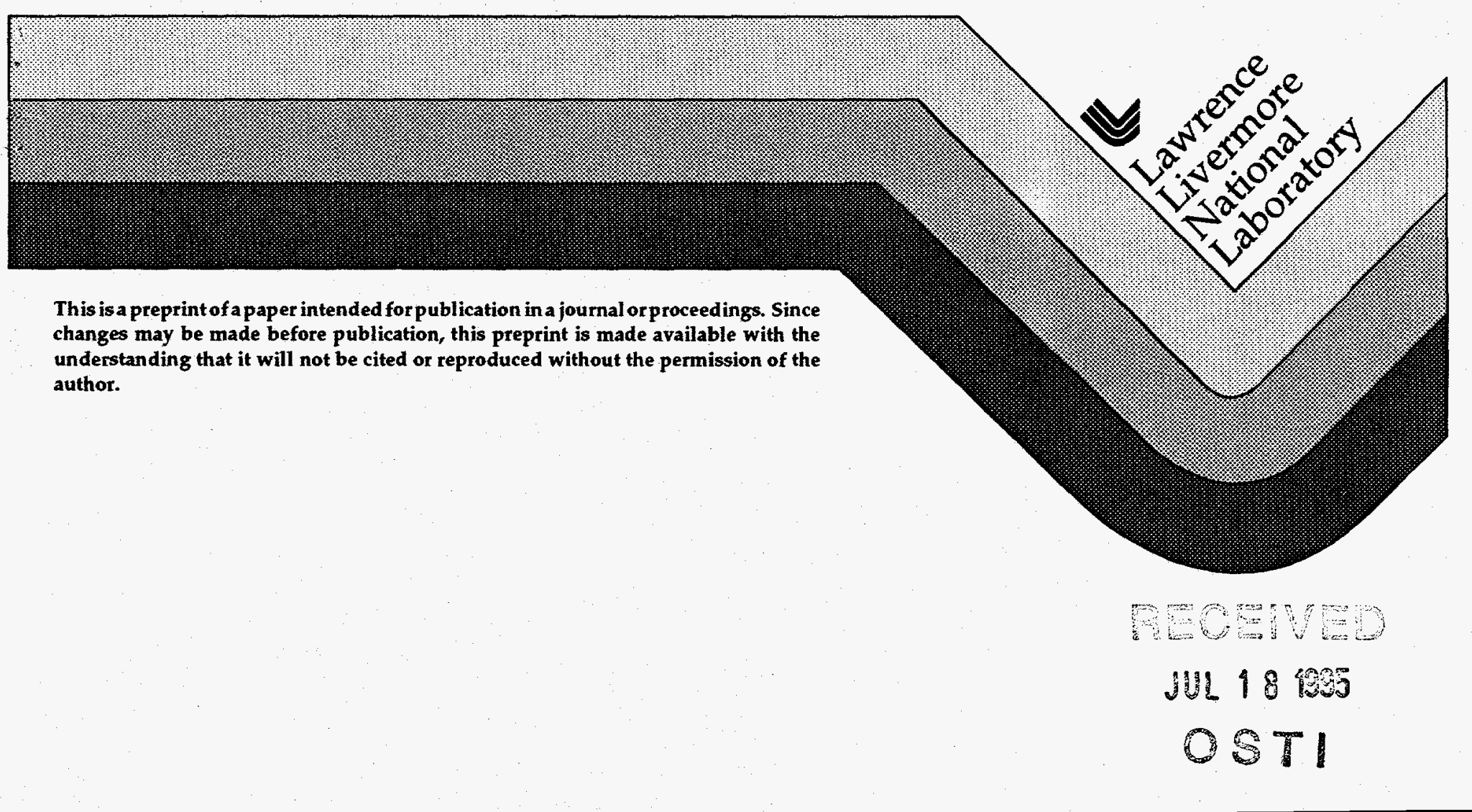




\section{DISCLAIMER}

This report was prepared as an account of work sponsored by an agency of the United States Government. Neither the United States Government nor any agency thereof, nor any of their employees, make any warranty, express or implied, or assumes any legal liability or responsibility for the accuracy, completeness, or usefulness of any information, apparatus, product, or process disclosed, or represents that its use would not infringe privately owned rights. Reference herein to any specific commercial product, process, or service by trade name, trademark, manufacturer, or otherwise does not necessarily constitute or imply its endorsement, recommendation, or favoring by the United States Government or any agency thereof. The views and opinions of authors expressed herein do not necessarily state or reflect those of the United States Government or any agency thereof. 


\section{DISCLAIMER}

Portions of this document may be illegible in electronic image products. Images are produced from the best available original document. 


\section{Analysis of Near-Field Thermal and Psychometric Waste Package Environment Using Ventilation}

\section{G. Danko}

Mackay School of Mines University of Nevada, Reno Reno, NV 89557

(702) 784-4284
T.A. Buscheck and

J.J. Nitao

Earth Science Dept. L-206, P.0. Box 808

Lawrence Livermore

National Laboratory

(510) 423-9390

(510) 423-0297

\section{INTRODUCTION}

The ultimate objective of the $\mathrm{Ci}-$ vilian Radioactive Waste Management System (CRWMS) Program is to safely emplace and isolate the nations' spent nuclear fuel (SNF) and radioactive wastes in a geologic repository. Radioactive waste emplaced in a geologic repository will generate heat, increasing the temperature in the repository. The magnitude of this temperature increase depends upon (1) the heat source, i.e. the thermal loading of the repository, and (2) the geologic and engineered heat transport characteristics of the repository.

Several aspects of thermal loading, including density, age, burnup, and enrichment of the heat-producing nuclear waste have been under extensive investigation. These studies assumed simplified geologic heat transport characteristics: some used pure heat conduction in the rock [1-6], while others applied largescale hydrothermal models $[7-12]$.

Only a few studies have addressed the thermal effects of the engineered heat transport characteristics of a conceptual repository. However, these characteristics can be designed to provide better repository performance using thermal management techniques. Analyses of ventilation affecting engineered characteristics have been conducted to explore the potential of maximum temperature reduction without reducing the heat source, i:e., the thermal loading of the repository $[13-16]$. Other studies analyzed passive cooling enhancement techniques, such as heat pipes or thermal rock bolts, in order to reduce the temperature increase produced by the thermal loading [17-19]. The combination of thermal enhancement and ventilation was also analyzed $[20,21]$. These techniques could affect waste containment and isolation and the ability to operate and monitor the repository. Therefore, thermal loading and the heat transport characteristics of the repository, are both critical elements affecting the thermal and overall performance of the repository system.

Thermal management techniques currently under investigation include ventilation of the emplacement drifts during the preclosure period which could last as long as 100 years. Understanding the amount of heat and moisture removed from the emplacement drifts and near-field rock by ventilation, are important in determining performance of the engineered barrier system (EBS), as well as the corrosive environment of the waste packages, and the interaction of the EBS with the near-field host rock. Two important issues are (1) the history of the rock (or drift wail) temperatures, and (2) the history of the relative humidity of the air in the emplacement rooms.

Temperature and humidity calculations were presented [23] based on VTOUGH (vectorized transport of unsaturated groundwater and heat) simulations [24] assuming no ventilation or air infiltration in the repository. Consequently, only water redistribution in the rock was considered along with no permanent rock drying taking place towards the air in the drift. Therefore, the results did not take into consideration the potential benefits that may result due to (1) permanent rock drying, and (2) dilution of vapor concentration caused by natural or forced ventilation during pre-closure. 
Temperature and moisture transport calculations were presented based on the MTECS (Mackay Thermal Enhancement and Climate simulation) model $[14,15,17,26]$ assuming various ventilation scenarios in the repository. It was assumed that the wetness on the drift surface remained constant during the pre-closure period for the simplified climate model applied to drift emplacement. The results showed that a significant amount of water, e.g. 0.72 metric tons per linear meter per year, can be removed by the air. This prediction was found feasible by an independent hydrothermal calculation [8], applying a simplified cavity model using TOUGH [25]. However, due to the assumption that the wetness is constant instead of decreasing, the amount of evaporation during extended drying is overestimated. Consequently, none of the models in their present form can predict a realistic psychometric environment for the waste packages.

Since radionuclide releases and repository system performance are significantly affected by the corrosion rate related to the psychometric environment, it is necessary to predict the amount of heat and moisture that are removed from the repository horizon using a realistic model for a wide range of thermal loading. This can be realized by coupling the hydrothermal model of the rock mass to a ventilation/climate model which includes the heat and moisture transport on the rock-air interface and the dilution of water vapor in the drift.

This paper deals with the development of the coupled model concept, and determination of the boundary conditions for the calculations.

\section{MODEL CONCEPT}

The focus of this work is the development of a near-field hydrothermal ventilation/psychometric coupled model based on coupling VTOUGH with MTECS for the analysis of waste package environment and near-field rock drying in a few selected cases.

The VTOUGH hydrothermal code is a Lawrence Livermore National Laboratory's enhanced version of the TOUGH code developed by Lawrence Berkeley Laboratory [24]. This code is an effective continuum model capable of simulating the coupled transport of water, vapor, air, and heat in fractured porous media. The model includes boiling and condensation effects, the convection of latent and sensible heat, and thermal radiation.
The MTECS [26] thermal model is developed for the calculation of air temperature and humidity in the emplacement drifts of a nuclear waste repository. A drift is heated partly by waste containers that are emplaced within the drift being simulated, and partly by those emplaced in the neighboring drifts. The specific layout of the waste containers is taken into account using the rock mantle temperature model, MTM. Ventilating air temperature and humidity are simulated using the drift climate model, MCM. The coupled solution of $M T M$ and $M C M$ is provided by the algorithm of the MTECS model.

The MTM model-element [25] is developed to calculate the time-dependent near- and far-field, 3-D temperature distribution in a high-level nuclear waste repository. The method is a finite element scheme with respect to the time division, and a boundary element scheme in the space domain. The heat conduction in the rock is calculated by matrix-vector multiplications in which the transfer matrices represent the 3-D, time-dependent heat conductance, and the vectors represent variable heat sources: Convective or latent heat transport forms, caused by ventilation, cooling enhancement devices, or a temperature and timedependent moisture evaporation, can be included using a set of matrix equations. The method requires the spacial meshing of the boundary surfaces where heat conduction is interfaced with other forms of heat transport. However, spatial division of the rock mass in pure heat conduction areas is not needed, therefore, eliminating the need for using an extremely large number of meshes and elaborate boundary condition definitions, which would be needed if a conventional, finite difference or element code were applied.

The MCM model-element [26] is based on an iterative, numerical solution of a set of differential equations governing the heat and moisture transfer processes.

The model accounts for radial heat conduction in the rock around the drift, and heat convection, as well as radiation on the drift wall. The model also provides a basis for an estimate of the moisture and latent heat removal from the drift wall due to ventilation. The method uses stepwise approximations of the continuous variations of temperatures and heat fluxes at each tunnel cross section. This time division transforms the time-variables into vectors, and the functional relationships of these variables into matrices, to provide compatibility with the MTM. 
In the MTECS algorithm, the MCM is interfaced to the MTM through a time- and space-variable rock mantle temperature function. An adjustable drift surface wetness factor is included, in order to accommodate hydrothermal simulation for predicting rock mantle drying. In turn, the MTM, using variable heat sources and sinks as well as constant matrices, allows the efficient re-calculation of the space-variable vector of the rock mantle temperature function. This is needed if a repository-scale ventilation, or rock drying in the mantle, significantly modifies the original heat source distribution.

The coupling of VTOUGH with MTECS is realized iteratively:

Step 1.

Air temperature and partial vapor pressure distributions are calculated longitudinally along a representative emplacement drift in a 3$D$ panel using MTECS and assuming an initial wetness factor distribution on the drift wall.

Step 2

Using the wall temperature and partial vapor pressure results from the MTECs calculation for a short longitudinal drift segment as boundary conditions, the hydrothermal transport in the rock wall is calculated using VTOUGH assuming a 2$D$ drift array. In this way, the total wall heat and moisture/vapor flux is calculated from the VTOUGH hydrothermal model for the drift segment. The calculation is repeated for all or only a reduced number of representative drift sections.

Step 3 .

The wall temperature, vapor pressure, heat, and moisture/vapor flux values are used to calculate an equivalent wetness factor for each drift segment; this result is compared with the initial or previous wetness value, and steps $1-3$ are repeated until convergence is reached for each longitudinal drift section.

Using the equivalent wetness factor as the controlled parameter between VTOUGH and MTECS, a fast-converging iteration procedure can be achieved. Since the equivalent wetness factor is modified according to the VTOUGH simulation, the heat and moisture flux will satisfy the VTOUGH hydrothermal simulation in each longitudinal drift section which has been selected. The heat and moisture flux will also satisfy the MTECS air temperature and humidity simulation.

The roles that VTOUGH and MTECS play in the coupled simulation can be summarized as follows:

\section{VTOUGH:}

It provides wall heat and moisture flux for pre-selected drift sections, based on a 2-D simulation, in the $x-z$ domain.

MTECS :

(1) It provides coupled boundary conditions (balanced drift surface temperature and vapor pressure from incoming air parameters and local convection, radiation, and latent heat transport in each section) for VTOUGH, and (2) it provides continuous air climate and rock surface temperature calculations between representative segments, where balanced, coupled simulations are performed. This calculation is based on using nonlinear interpolation of the equivalent wetness factor between pre-selected segment locations, in order to reduce the number of longitudinal sections and corresponding vTOUGH iterations which is needed for coupled simulations.

\section{REPOSITORY SYSTEM STUDIED}

The repository system for the present analysis consists of a single emplacement panel whose area is approximated by a rectangular domain of $1060 \mathrm{~m}$ by $2550 \mathrm{~m}$, shown in Figure 1 . The emplacement drifts, all $5 \mathrm{~m}$ in diameter, run along the shorter length of the panel. The containers, all equalized to be $5 \mathrm{~m}$ long and $1.2 \mathrm{~m}$ in diameter, are laid down on the floor of the drifts in cradles shown in Figure 2, which also depicts the thermal interactions between the containers, the drift wall, and the ventilating air. The most critical drift situated in the center of the panel is selected for the analysis. Eight cases summarized in Table 1 were specified using various waste package and drift spacing. Each waste package is represented by an equalized heat load, characteristic to an "older fuel first," 26-years-old fuel with an initial heat load of $7.284 \mathrm{~kW}$ at the time of the emplacement. The eight different cases in Table 1 represent three different area mass loading scenarios, solely determined by the spacing of the waste packages and the drifts. 


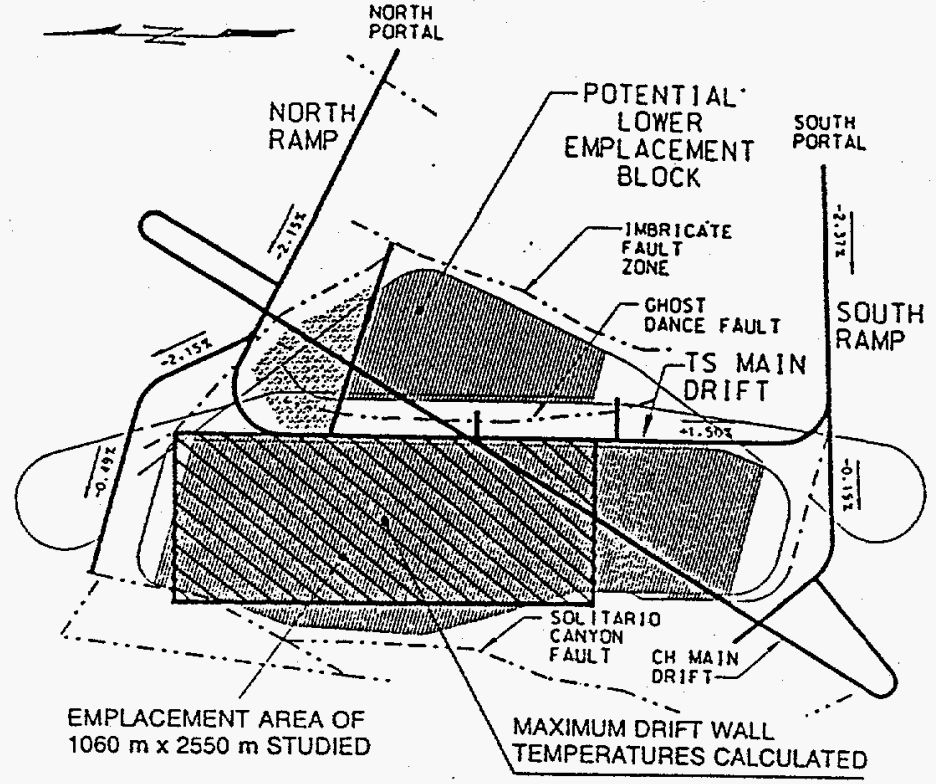

Figure 1. The proposed repository system layout.

CONVECTION FROM CONTAINER TO ORIFT
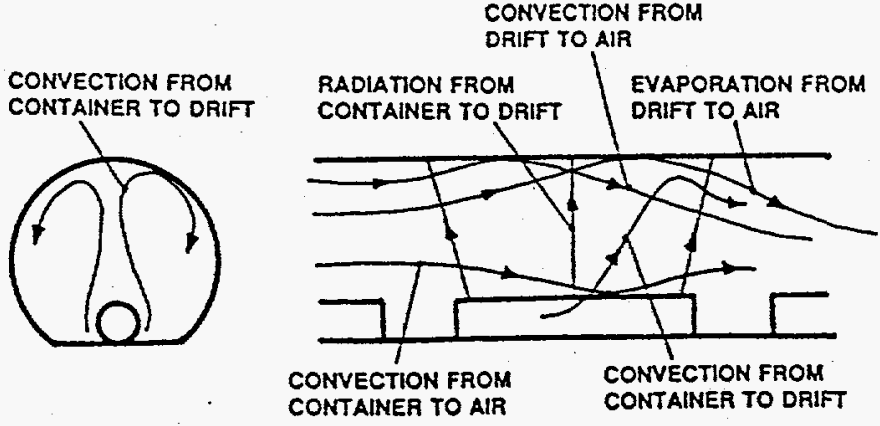

Figure 2. Container emplacement with the thermal interactions.

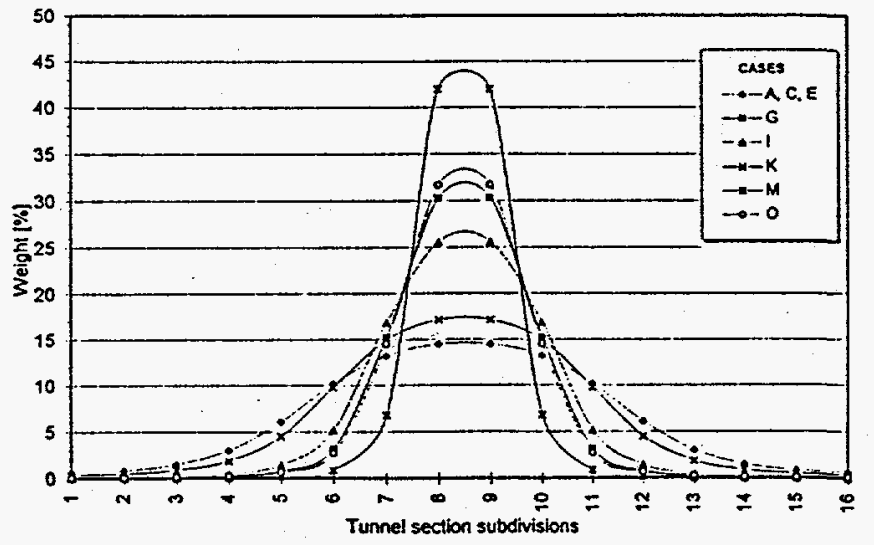

Figure 3. Weight distributions in Cases A-O.
BOUNDARY CONDITIONS FOR THE COUPLED MODEL

It is imperative to determine the longitudinal variation of drift surface temperatures around the waste packages at zero air flow, in order to select adequate discretization along the drift length for the MTECS model. Cases $A-O$ in Table 1 include relatively large ratios between the waste package center distances and the container length, ranging from 3.2 to 10.6 . These conditions warrant a detailed analysis of the variations of temperatures.

Since thermal radiation dominates when no ventilation is provided, a simplifying assumption was made. According to this simplification, the longitudinal distribution of the overall (convective plus radiative) heat transfer between the containers and the drift wall equals that of the radiation. The longitudinal distribution of heat radiation over 16 sections of a waste package interval in the middle of the drift was calculated numerically based on the summation of the radiation view angles of all the $1-\mathrm{m}$ long container segments radiating heat to each of the 16 segments. The normalized weight distribution of the container heat load over the 16 segments are shown in Figure 3 for cases $A-I$. This percentage weight distribution is used to spread the container heat dissipation over each section for longitudinal temperature calculation with the MTM model-element of the MTECS.

Table 1. Areal mass load, waste package and drift spacing.

\begin{tabular}{|c|c|c|c|c|c|c|c|c|}
\hline & \multicolumn{8}{|c|}{ CASES } \\
\hline & $\mathbf{A}$ & C & $\mathbf{E}$ & $\mathbf{G}$ & I & $\mathbf{K}$ & $\mathbf{M}$ & 0 \\
\hline $\begin{array}{l}\text { Areal mass density } \\
\text { [MTU/acre] }\end{array}$ & 25 & 36 & 83 & 25 & 36 & 83 & 25 & 36 \\
\hline $\begin{array}{c}\text { Number of waste } \\
\text { packages }\end{array}$ & 67 & 67 & 67 & 31 & 37 & 56 & 21 & 29 \\
\hline $\begin{array}{l}\text { Waste package } \\
\text { spacing [m] }\end{array}$ & 16 & 16 & 16 & 34.9 & 29.1 & 19.1 & 52.9 & 36.7 \\
\hline $\begin{array}{l}\text { Number of drifts } \\
\text { left of center }\end{array}$ & 16 & 24 & 55 & 36 & 43 & 66 & 55 & 55 \\
\hline Drift spacing [m] & 76 & 52.8 & 22.9 & 34.9 & 29.1 & 19.1 & 23 & 23 \\
\hline
\end{tabular}




\begin{tabular}{|lll|}
\hline Legend: & $\mathrm{c}: 6^{\text {th }}$ and $11^{\text {th }}$ sections & f $: 3^{\text {th }}$ and $14^{\text {th }}$ sections \\
a $: 8^{\text {th }}$ and $9^{\text {th }}$ sections & d $: 5^{\text {th }}$ and $12^{\text {th }}$ sections & g $: 2^{\text {nd }}$ and $15^{\text {th }}$ sections \\
b $: 7^{\text {th }}$ and $10^{\text {th }}$ sections & e $: 4^{\text {th }}$ and $13^{\text {th }}$ sections & h $: 1^{\text {st }}$ and $16^{\text {th }}$ sections \\
\hline
\end{tabular}
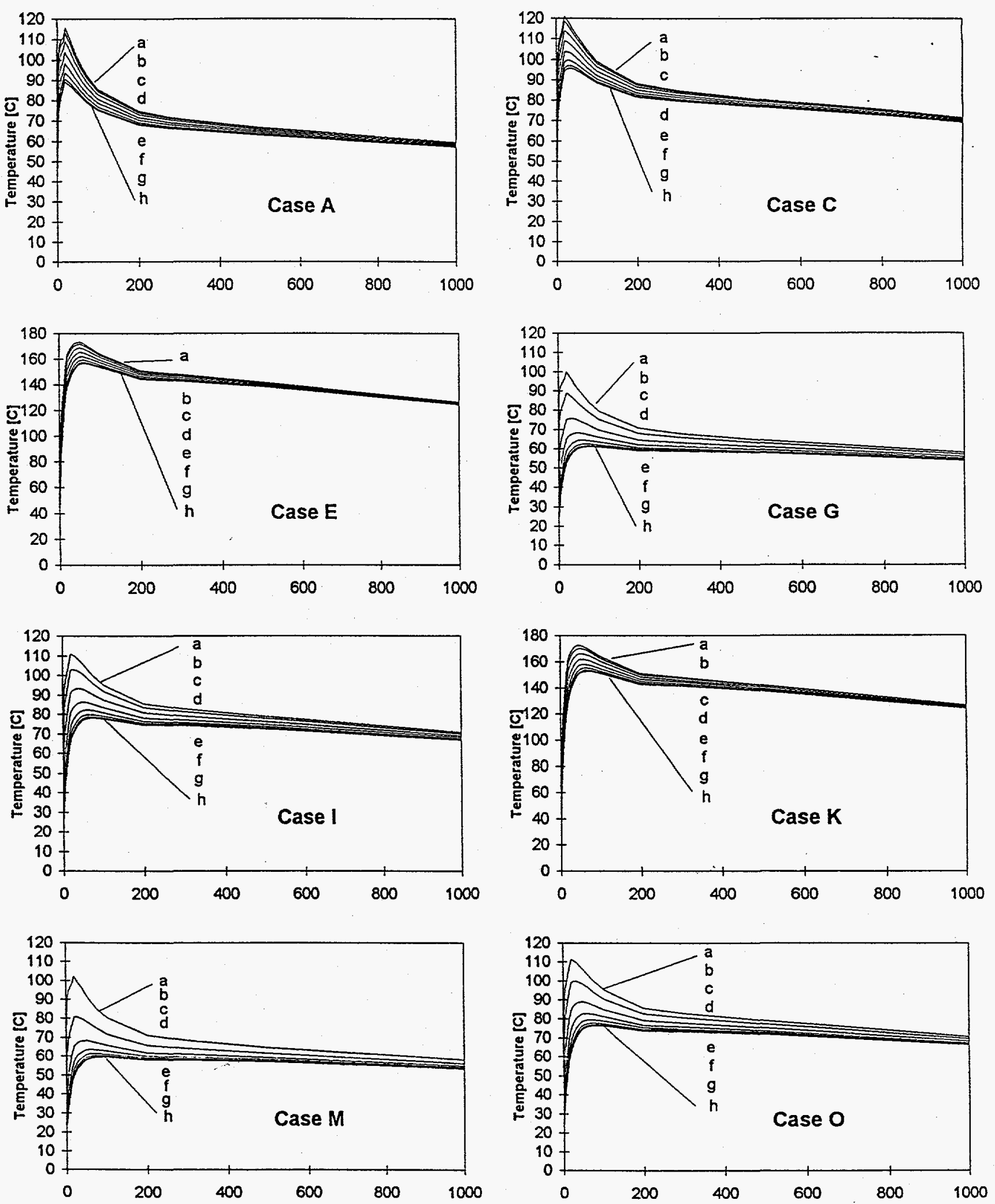

Figure 4 Temperature histories over 16 sections in the middle part of the center drift for cases A - O 
In the MTECS model, each container was represented by its heat source at its exact position in the emplacement panel. The container sections were subdivided into 16 sections in the center drift. The temperature histories over these sections in the middle of this drift is shown in Figure 4 for cases $A-I$. In addition to modeling uneven heat load distribution, the drift wall temperature histories were also calculated assuming a longitudinally smeared heat source, modeled by an even source weight distribution. A summary evaluation of these cases is provided in Table 2 .

The drift wall temperatures for all cases, as shown in Figure 4 and Table 2, vary significantly over the length of the drift section analyzed. This variation implies that a smeared heat source along the drift length cannot be used for analyzing the thermal effects of low and moderate ventilation, in which heat radiation is a significant transport component. Therefore, 16 division of the waste package spacing along the drift length will be required in the MCM simulations. The large number of divisions on the air-rock boundary underscores the importance of applying interpolation principles described in the model concept.

Only case $G$ represents borderline boiling conditions. The drift wall temperature difference of $46^{\circ} \mathrm{C}$ is quite high, being close to 50 \% of the maximum temperature. Ventilation may not be necessary for temperature reduction, but it can be advantageous in reducing the temperature difference.

Cases $\mathbf{E}$ and $\mathrm{K}$ represent persistent above-boiling conditions over the entire drift section for over 1000 years. Both cases can be used to study the effect of rock drying when adequate ventilation is provided.

Cases $A$ and $C$ represent above-boiling conditions for 50-90 years along 5075 percent of the drift section analyzed. These cases provide the best examples for analyzing the benefit that can be achieved by applying ventilation for 50100 years. It is anticipated that belowboiling conditions can be provided for these cases using ventilation.

Cases $I, M$, and $O$ also represent above-boiling conditions for 15-80 years along 12-25 percent of the drift section analyzed. In these cases a longitudinal smearing of the heat load can reduce the maximum drift wall temperatures below the boiling point of water, as shown in last column of Table 2. The distribution of heat along the length can be achieved using passive cooling enhancement devices, e.g. heat pipes that are laid between the waste packages. The maximum temperatures can also be reduced to below-boiling conditions using moderate ventilation.

\section{CONCLUSIONS}

The enhanced computational capability being developed through coupling of a thermohydrologic and ventilation code will be of substantial benefit in assessing some of the thermal management issues that the program needs to address. Further effort will be done to evaluate a range of thermal loading cases to address whether or not ventilation can be used to enhance performance by removal of heat and moisture; mitigate localized high temperatures resulting from waste package spacing and fuel variability; and/or allow for easier retrieval of the containers. These results will be of benefit to the program in evaluations of options which are required by the Program Thermal Loading strategy.

The repository system with eight specific cases that has been selected for ventilation studies represent a meaningful test data set to study the thermal/psychometric climate parameters that can be significantly affected by ventilation in the emplacement drifts during the preclosure time period of 25-100 years.

cased $\begin{aligned} & \text { The drift wall temperatures for all } \\ & \text { analyzed vary significantly over }\end{aligned}$ the length of the drift section. There-

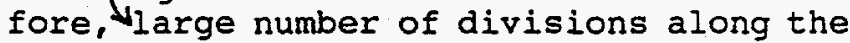
drift length will be required in the $M C M$ simulations, underscoring the importance of applying interpolation principles described in the model concept.

\section{ACRNOKLEDGEMENTS}

The research was supported by a grant from the DOE Yucca Mountain Project Office under Block Grant contract DEFG08-90NV10891. The contributions of $\mathrm{Mr}$. Cs. Mezei and Mr. J. Phillips, Mackay School of Mines, and Mr. C.H. Lai, Lawrence Livermore National Laboratory, in computer programming and simulation work are highly appreciated. 
Table 2. Summary of temperature calculations - no air flow

\begin{tabular}{|c|ccccc|}
\hline Case & $\begin{array}{l}\text { Maximum } \\
\text { Drift Wall } \\
\text { Temperature } \\
{\left[{ }^{\circ} \mathrm{C}\right]}\end{array}$ & $\begin{array}{l}\text { Maximum } \\
\text { Drift Wall } \\
\text { Temperature } \\
\text { Difference } \\
{\left[{ }^{\circ} \mathrm{C}\right]}\end{array}$ & $\begin{array}{l}\text { Duration of } \\
\text { Above Boiling } \\
\text { Conditions } \\
\text { [Years] }\end{array}$ & $\begin{array}{l}\text { Percent of } \\
\text { Length Above } \\
\text { Boiling } \\
{[8]}\end{array}$ & $\begin{array}{c}\text { Drift Wall } \\
\text { Peak Temp. } \\
\text { With Even } \\
\text { Source Weight } \\
\text { [ }{ }^{\circ} \text { C] }\end{array}$ \\
\hline A & 115 & 28 & 50 & 50 & 102 \\
C & 120 & 28 & 90 & 75 & 107 \\
E & 172 & 28 & $>1000$ & 100 & 160 \\
G & 100 & 46 & 1 & 6 & 71 \\
I & 112 & 42 & 80 & 25 & 88 \\
K & 172 & 30 & $>1000$ & 100 & 161 \\
M & 104 & 50 & 15 & 12 & 67 \\
O & 115 & 46 & 80 & 20 & 85 \\
\hline
\end{tabular}

\section{REFERENCES}

1. D.J. Ruffner, J.A. Blink, and T.W. Doering, (1993). "Drift Emplaced Waste Package Thermal Response," Proceedings, 4th Annual International Conference on High-Level Radioactive Waste Management, Las Vegas, NV, April, pp. 538-543.

2. E. E. Ryder, (1993). "Comparison of Predicted Far-field Temperatures for Discrete, and smeared Heat Sources," Proceedings, 4th Annual International Conference on HighLevel Radioactive Waste Management, Las Vegas, NV, April, pp. 841-846.

3. J.F. Holland, (1993). "The Results of Near-Field Thermal and Mechanical Calculations of Thermal Loading Schemes," Proceedings, 4th Annual International conference on HighLevel Radioactive Waste Management, Las Vegas, NV, May, pp. 868-873.

4. J.L. Girotto, L. Chaudon, and J.M. Hoorelbeke, (-1992). "Impact of HLW Thermal Output on Repository Design," Proceedings, 3rd Annual International Conference on HighLevel Radioactive Waste Management, Las Vegas, NV, May, pp. 779-783.

5. S. Moujaes and A. Bhargava, (1994). "Simulation of Heat Transfer Around a Canister Placed Horizontally in a Drift," Proceedings, 5th Annual International Conference on HighLevel Radioactive Waste Management, Las Vegas, NV, May, pp. 801 - 808.

6. R.H. Bahney III, and T.W. Doering, (1994). "Thermal Response of the Waste Package/MPC and EBS," Proceedings, 5th Annual International Conference on High-Level Radioactive Waste Management, Las Vegas, NV, May, pp. $809-815$.

7. Y.W. Tsang, and K. Pruess, (1987). "A study of Thermally Induced Convection Near a High-Level Nuclear Waste Repository in Partially Saturated Tuff," Water Resour. Res., 23, pp. $467-47 \overline{9}$.

8. K. Pruess, and Y. Tsang, (1993). "Modeling of strongly Heat-Driven Flow Processes at a potential HighLevel Nuclear Waste Repository at Yucca Mountain, Nevada," Proceedings, 4th Annual International Conference on High-Level Radioactive Waste Management, Las Vegas, NV, May, pp. 568-575.

9. T.A. Buscheck, and J.J. Nitao, (1993). "The Analysis of Repository-Heat-Driven Hydrothermal Flow at Yucca Mountain," Proceedings, 4th Annual International Conference on High-Level Radioactive Waste Management, Las Vegas, NV, MaY, PP. 847-867. 
10. T.A. Buscheck, J.J. Nitao, and S.F. Saterlie, (1994). "Evaluation of Thermo-Hydrological Performance in Support of the Thermal Loading Systems study," Proceedings, 5th Annual International conference on High-Level Radioactive waste Management, Las Vegas, NV, May, pp. 592-610.

11. S. Mishra, (1994). "Subrepository Scale Hydrothermal Analysis in Support of Total System Performance Assessment at Yucca Mountain," Proceedings, 5 th Annual International Conference on High-Level Radioactive waste Management, Las Vegas, NV, May, pp. 1202-213.

12. R.R. Eaton, (1994). "Effect of Fractures on Repository Dryout," Proceedings, 5th Annual International conference on High-Level Radioactive Waste Management, Las Vegas, NV, May, pp. 2442-2449.

13. T.A. Buscheck, and J.J. Nitao, (1992). "The Impact of Thermal Loading on Repository Performance at Yucca Mountain," proceedings, 3 rd Annual International Conference on High-Ievel Radioactive waste Management, Las Vegas, NV, April, pp. 1003-1017.

14. G. Danko, (1992). "Modeling of the Ventilation for Emplacement Drift Re-entry and Rock Drying," Research Report, submitted to M\&O/MK/DOE, June, pp. 1-29.

15. G. Danko, and P. Mousset-Jones, (1992). "Coupled Heat and Moisture Transport Model For Underground Climate Prediction." Proceedings, 3 rd Annual International Conference on High-Ievel Radioactive Waste Management, Las Vegas, NV, April, pp. 790-798.

16. H. Yang, and K.K. Bhattacharyya, (1994). "Ventilation Considerations for Repository subsurface Advanced Conceptual Design," Proceedings, 5th Annual International Conference on High-level Radioactive Waste Management, Las Vegas, NV, May, PP. 530-537.

17. G. Danko, and P. Mousset-Jones, (1993). "Modeling of the Ventilation for Emplacement Drift Re-entry and Rock Drying," Proceedings, 4th Annual International Conference on High-Level Radioactive waste Management, Las Vegas, NV, April, Pp.
$590-599$.

18. G. Danko and P. Mousset-Jones, (1990). "The Analysis of Horizontal Cooling Enhancement for Nuclear Waste Container Emplacement," Proceedings, Ist Annual International Conference on High-Level Radioactive Waste Management, Las Vegas, NV, April, pp. 667-674.

19. G. Danko, P. Mousset-Jones, and R.A. Wirtz, (1990). "The Analysis of a New High-Level Nuclear Waste Container Emplacement Layout," Int. Symposium on Unigue Underground Structures, Denver, Co, June, Pp. 55/1-55/18.

20. G. Danko, (1994). "The Application of Thermal Rock Bolts in the Thermal Design of a Nuclear Waste Repository," Proceedings, 5th Annual International Conference on HighLevel Radioactive Waste Management, Las Vegas, NV, May, pp. 890-898.

21. G. Danko, (1991). "Emplacement Drift Temperature Reduction by Cooling Enhancement and Ventilation," Proceedings, 2nd Annual International Conference on $\mathrm{High-}$ Level Radioactive Waste Management, Las Vegas, NV, April-May, pp. 15851593.

22. G. Danko, (1993). "Thermal Loading Studies Using Cooling Enhancement and Ventilation," Nuclear Technology, Vol. 104, pp. 358-371.

23. T.A. Buscheck, (1994). "Relative Humidity Calculations," personal communication.

24. J.J. Nitao, (1989). "V-TOUGH - An Enhanced Version of the TOUGH Code for the Thermal and Hydrologic Simulation of Large-Scale Problems in Nuclear Waste Isolation," UCID21954, Lawrence Livermore National Laboratory, Livermore, CA.

25. K. Pruess, (1987). "TOUGH User's Guide, " NUREG/GR-4695, SAND86-7104,

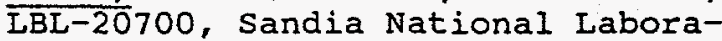
tories, Albuquerque, NM.

26. G. Danko, (1994). "Ventilation and Cooling Enhancement for High-Level waste Repositories," Semi-Annual Research Report to DOE, PP. 1-93. 